\title{
Contro il male del tempo: The Dream of Gabriele D'Annunzio
}

\author{
e forse sua sentenza è d'altra guisa \\ che la voce non suona, ed esser puote \\ con intenzion da non esser derisa.
}

Paradiso. IV 55-57

Dannunzianism has most often been misconceived of as an ideology: I mean by this both that as ideology it has seldom been recognized for what it is, and that ultimately it may be something more (or less) than an ideology. Paolo Valesio, in his seminal piece "The Lion and the Ass" (67-82), has effectively shown the extent to which traditional approaches to D'Annunzio have 'framed' him as an ideological precursor of fascism-a fascism that, in fact, is ideologically closer to the socialdemocratic populism that has exorcized D'Annunzio from the literary-political canon of good taste. $\mathrm{He}$ then goes on to (re)construct an ideological frame for D'Annunzio that better suits the aristocratic position he upheld. ${ }^{1}$ But this opposition of ideologies in the reading of D'Annunzio is assuredly not a simple one of black and white: ideological duplicity is written into the Dannunzian text. The wrong, or at least vulgar, reading is always possible with D'Annunzio, and is coextensive with the more properly Dannunzian reading of the sort Valesio proposes.

For an example of how this duplicity operates, we can turn to a scene from D'Annunzio's most accomplished novel, Il Fuoco (1900), in which the hero, Stelio Effrena, delivers an ex tempore speech entitled the Allegoria dell' Autunno to an eager Venetian audience. As Valesio has pointed out, Stelio's audience is a double one: on the one hand, the ostensible target of the orator's message is the "moltitudine" (which, for all that it is formed by the upper crust of Italian society, most frequently figures as a seething animal mass, a monstrous chimera); on the other, the privileged target of the orator's eros turns out to be his group of individualistic disciples ("The Beautiful Lie" 75-76). Analogous, no doubt, to Nietzsche's "free spirits," they are capable of a subtler interpretation of the doctrine his speech encloses. The reception of the message will differ according to who receives it: the crowd will take it literally; the initiated will find in it an other meaning-Stelio's speech is, after all, an "allegoria." 
To pursue that other meaning would be to further the non-vulgar account of Dannunzian ideology that has been developing over the past decade. But the task in this paper is a different one: to map out the pre-text of that duplicitous ideology, or, to use the terminology of Valesio's Novantiqua, the "rhetoric" that undermines his text and its ideologies (esp. 61-144). The opposition between the vulgar and allegorical reading of D'Annunzio is not a black and white one: the hidden meaning does not stand without the apparent one; both, in the final analysis, resemble each other as instances of ideology. Some point of articulation, some common ground, is thus implicit between them. As it happens, this point is made explicit in the passage from Il Fuoco that we have been considering: Stelio's speech is not rendered as an harmonious whole but, rather, is broken up and interspersed with the narrator's commentary on it. The commentary not only allows us to identify the two ideological targets of Stelio's oration, but opens up the space of a third audience-one that registers with the narrator the entire process of ideological presentation. If we accept Valesio's definition of ideology as "decayed rhetoric-rhetoric that is no longer the detailed expression of strategies at work in specific discourses" (66; italicized in text), then this commentary is a properly rhetorical one since it makes patent the various strategies at work in generating and formulating the ostensibly full speech of the orator, his "parola dominatrice."

In commenting on the constitution of Stelio's speech, the narrator destabilizes the ideological message it bears; the strategies of persuasion that make up the doctrine come to light, and the common ground of ideologies - be they vulgar or aristocratic-is revealed. If we keep in mind the fact that the Allegoria is not only Stelio's speech (in whatever sense a discourse can be ascribed to a fictional character) but a verbatim duplication of a speech given by the author in 1895, then it becomes clear that D'Annunzio is himself engaged in the task of mapping-out the rhetorical pre-texts of his own ideology. Our task is simplified; it becomes less deconstructive than descriptive as we follow the unpacking of ideology into its rhetorical components that typifies Dannunzianism. His own ideology is no less fictional than Stelio's, and he knows it-a fact which is implicit in all of what we will be calling his 'post-decadentist' writings (by virtue of their ideological duplicity) and sometimes, as in Il Fuoco or the work we will be considering here, Sogno d'un mattino di primavera (1897), made explicit. The authoritative fullness that is the dream of all ideology is never anything more (or less) than a dream. The aggressive unity of the Dannunzian text, the apparently unbroken surface of an ideology that proclaims - with all ideologies-that time and its evil have been mastered, dissolves into a study of the diffuse and partial strategies that 
make up the underlying reality of this text. As rhetorician, D'Annunzio shows up the intimate relationship between the will to persuasion and that will's hypostasis as ideology - be the ideology fascist, democratic, or Dannunzian.

******

The rhetorical-ideological cluster signalled here as 'Dannunzianism' emerges at an identifiable point in D'Annunzio's career as a response to the problem of decadence. It is adopted in what can be called-with important caveats-his post-decadentist writings, of which the Sogno, pre-text and protocol to a theatrical enterprise that openly confronts literary-political decadence, is among the first instances. Before studying the Sogno, a brief account of the years immediately preceding D'Annunzio's initiation into the world of politics and the theatre is in order; a generalized discussion of the historical significance of decadence and the Dannunzian response to it must be deferred until the concluding pages of this paper.

1893 saw the culmination of a phase in D'Annunzio's career: Trionfo della morte closed out the decadentist trilogy of the Romanzi della rosa; and a decade of Parnassian poetry reached its apex in the Poema paradisiaco. After this point his writing undergoes a fundamental and obvious change; as one critic puts it, "a partire dal ciclo del Giglio [Le Vergini delle rocce $(1895)^{2}$ ] il pessimismo cede il posto alla esaltazione dionisiaca della vita" (Jonard 38). The ostensible causes of this sea-change are well-known: he gains a more thorough familiarity with Nietzsche's work, and he discovers classical Greece on a yachting cruise in the Aegean. The consequent move to an optimistic register is not, however, limited to the adoption of a facile superomismo or a Maurassian classicism. If D'Annunzio registers Nietzscheanism as an ideology it is not "dans le sens légendaire et imbécile du mot" ; if he incorporates Greece in his text it is not the smooth surface of Hellenism but the agitated eros of tragedy that he explores. The shift from a decadentist pessimism to a dionysiac exultation is not the clean break of a conversion, the unproblematic assumption of a new ideology but, rather, a genealogical shift within the problematic of decadence, a problematic that generates D'Annunzio's entire career as a writer.

A good part of the dilemma facing the decadentist writer (as distinguished, say, from a Zola) lies in his sense of being alienated from an audience. The private relationship which the bourgeois novel, or lyric poetry for that matter, establishes between the writer and his readers is perceived as being more and more tenuous and no longer an adequate 
means of engaging audiences on the level of action. Whatever ideological position the writer upholds will either not realize itself, or, at best, will fall to the side of the world of values and action as a form of aestheticism. Such aestheticism may provide an efficient model of self-fashioning but does not, for the decadentist writer, seem to have any concrete effect on others. At the turn of the century the question remains open as to whether the crisis in the presentation of ideology, a crisis that decadentism marks, can be resolved in the theatre. What is important to stress here is that the writer's sense of isolation and ineffectiveness results in a twofold cynicism: on the one hand, a contempt for the others, the barbarians, who cannot or will not be actively engaged by the writer; on the other, a cynicism about the writer-hero, that moi who is counterpoised against an absent or hostile readership. Since a major spur to D'Annunzio's efforts in the theatre would appear to be the revival of an effective heroism (understanding by 'hero' the vehicle of a writer's ideology, his model for action), it is worth recalling, briefly, the distinguishing features of the decadentist (non)hero, and the nature of the writer's problematic distance from him.

Of Giorgio Aurispa, protagonist of the Trionfo, we are informed:

Quest'uomo intellettuale, chi sa per quale influsso di conscienze ataviche, non poteva rinunziare ai sogni romantici di felicità. ... Questo contrasto bizzarro fra la lucidità del pensiero e la cecità del sentimento, tra la debolezza della volontà e la forza degli istinti, tra la realtà e il sogno, produceva su lui disordini funesti Prose di romanzi 1:812-13

The narrator's distance from his hero here elicits a negative characterization of Giorgio's dreams, as well as a vocabulary of sickness and health that portrays an organism in disorder. The narrative 'commentary' of $I l$ Fuoco has not yet emerged as a means of regulating what is here an unhappy duplicity in the subject. The narrator's language is a critical one by which the writer takes some distance from the heroic self; yet this distance is not a welcome one inasmuch as the writer's own dream requires that he project himself onto the hero as an expression of his aristocratic convictions. The decadentist novelist writes out of this double-bind: on the one hand, he wishes to confirm the hero as an instance of the "aristocratie d'âme" that he upholds in the face of a degraded world (Huysmans $12: 28)$; on the other, he is pushed toward a critical analysis of his own hero that displaces his "rarità" and reveals it as pathological. This critical analysis, fully carried out, leads to a Proustian self-knowledge that the decadentist narrator, insistent upon the necessity of heroism, can never pursue whole-heartedly. The theatre, suppressing as it does the narrator in favor of the narrative, would appear to offer a field of immediacy less 
open to this vicious circle. In the generic shift from novel to theatre the private audience is left behind-the dramatist confronts his new, public audience: the masses.

The theatre and this public, potentially political confrontation exceed the enclosed, rarefied world of the decadentist novel: Huysmans speaks of "l'ignoble industrie du théâtre" and characterizes politics as "cette basse distraction des esprits médiocres" (A rebours, Oeuvres 7:40 and 288). For D'Annunzio they form a natural dyad in his move beyond decadence. As Ezio Raimondi has pointed out:

La carriera del drammaturgo e quella del tribuno cominciano insieme per il D'Annunzio nel momento in cui teatro e politica gli rivelano la realtà complessa della 'moltitudine,' che non è più soltanto un pubblico anonimo e distante ma una forza da conquistare in un dialogo diretto, in una liturgia essenzialmente fisica, 'd'un acre odore umano' (55).

The work with which he launches this dialogue, Sogno d'un mattino di primavera (written concurrently with his major tragedy La Città morta but represented earlier in 1897), differs from the theatrical works that proceed out of it inasmuch as it is not styled a "tragedia" but, rather, a "poema tragico." This conflation of genres is the first sign of what any reader cannot help but feel when confronting the Sogno, namely, "l'aspetto composito dello stile" (Gibellini 66). It falls into no one camp; indeed, I will argue that it is this composite quality that is the generating principle of its composition. For the Sogno is a commentary on other forms of discourse: upon examination, the potential unity of the text disaggregates into a collection of discursive strategies that are not yet set in or settled on a single ideology.

The Sogno stands as protocol to the theatrical, tragic enterprise: it pre-scripts and sheds anticipatory light upon it even as it reflects back upon the works already written. Despite its apparent imperfections, or, rather, because of them, it is a crucial document for understanding the rhetorical ground of D'Annunzio's work. To assert its importance is to oppose the often condescending tone adopted in discussion of the Sogni, one generally motivated by formal, generic concerns (the critic's nostalgia for 'propriety'), as we see in this typical instance:

Si sente che il dato propriamente scenico viene per cosìdire sovrapposto decorativamente su un motivo intimo o fantastico che non trova più la via per concretarsi in azione. ${ }^{4}$

The lack of a motive, the Sogno's failure to concretize itself in action, is not the simple structural failure it might at first appear; the failure signifies. 
To concretize an action would be to produce an alternative to decadence, to the "male del tempo" against which the work is dedicated in its epigraph. For D'Annunzio there can be no benignly oppositional way of combatting time's evil; to be against the evil of time can only mean to be up close to it, pressed against it, involved with it. The lack of a solution, one that would emerge by means of a dramatic action, is the sign of this involvement, the grounding of those actions that do occur in his theatre proper. ${ }^{5}$

To speak of the Sogno's 'decorativeness,' as the above critic does, raises the problem of the work's poetical quality. The problem of poetry is a fundamental one when reading the Sogno: in what sense is it the "poema" it claims to be? This question leads directly to another: what formal continuity exists between the writings of the decadentist poet of the Poema paradisiaco and those of the post-decadentist tragedian? The immediate answer is that both manifest important filiations with the contemporary poetic of symbolism. D'Annunzio's decadentist poetry is avowedly symbolist: an essential part of the decadentist project overlaps that of symbolism. If we are to believe Walter Binni's by-now classic formulation of that project, the overlap consists in their mutual adherence to a "nuova poetica come ricerca della musica" (109). Musicality would be at once the vehicle and the goal of such a poetic; symbols, a sort of musical notation, would effect a translation from the prosaic world to one in which the word is music. They herald, as Binni says, "la costatazione d'un mondo nuovo, d'una regione dello spirito inesplorato e basilare per ogni conoscenza e per ogni morale; la scoperta dello jenseits der Dinge come della radice vera della nuova poesia" (37). If symbolism and decadentism share the same telos-the synthesis of discords by means of poetic language- they do not exhibit a common attitude as to the possibility of achieving it. Simply put, the former is optimistic in this regard, the latter pessimistic. Throughout the Poema paradisiaco, for instance, we find the symbolist division of two worlds figured as an insuperable distance-as in "Hortus conclusus":

Giardini chiusi, appena intraveduti,

o contemplati a lungo pe' cancelli

che mai nessuna mano al viandante

smarrito aprí come in un sogno!

What is beyond the gate, beyond the thing, is never arrived at, is at best half-seen. Here D'Annunzio, in typical decadentist fashion, thematizes the symbolist project in terms of failure and incompleteness (the "mai nessuna mano," at once negative and synecdochal). An opening into the garden world, a world significantly voided of all humanity, is conceived of as merely a dream-possibility without substance, merely "un sogno non 
sognato mai." The ideal futurity it seems to offer collapses back into the prosaic facticity of the al di qua.

The internal consistency of the Sogno, its formal poetic unity, is established through a similar recourse to symbolism; no reader of D'Annunzio can be unaware of the prominent role symbolism plays in the organization of his work during this period. ${ }^{6}$ However, far from effecting a translation to a purified world, D'Annunzio's use of symbols is directed against the idealistic unity, the "armonia," that is its apparent goal. The enclosed garden of the Sogno offers a different topology and a different perspective than that of "Hortus conclusus"; far from being the alternative world, on the other side of the limen, it is that limen-a point of mediation between two worlds, a mid-way point of contention, of tension. As we learn from the opening didascalia, ${ }^{7}$ the dream-garden of the Sogno is situated between an inside and an outside, between two worlds symbolically marked off by the gem-like hardness of stone and the musical fluidity of water and fire. To one side, we are faced with an already created world, the Tuscan villa L'Armiranda-identified by its stone columns, statues, and sculptured architrave; to the other, we look toward a world that is yet to be, a utopic vision of elemental force- "A traverso un cancello, in fondo, si scorge il bosco selvaggio ove gioca il sole mattutino: visione di forze e di gioie senza limiti." 8 The insertion of a third space between the dualistically opposed villa and woods creates the possibility of narrative and temporality; the garden of appearance ("appare un giardino intercluso") becomes a fleeting presence intercalated between past and future, a confusing place of reconciliation, place of the dream.

D'Annunzio uses this dream-space as an experimental ground on which to enact, and thereby analyze, various emblematic discursive strategies; in their enactment they reveal their ultimate groundlessness. By contrast to the pattern set in the Vergini, where the hero confronts three different women as possible objects for his desire to procreate the future king of Rome, in the Sogno it is the audience which is presented with three possible discourses to choose from as adequate vessels of representation; we may call these discourses enthymematic, metonymic, and metaphoric. ${ }^{9}$ These discursive strategies are used, respectively, by the three main protagonists: the old keeper Teodata/the Doctor; the young hero Virginio; and the demented heroine Isabella. As we shall see, the first type of discourse belongs to analysts of the dream, the others to the dreamers themselvesbut they are all in a dynamic relation with each other, and all prove to be partial discourses (that is, both incomplete and biased). Fullness is absent from all of them; the fullness which is absent from the Sogno, but which D'Annunzio's theatre proper explores, is that of tragedy. Ideally, 
tragedy effects a catharsis, a cure: it achieves itself in something more than incompleteness. The conclusion of this paper will bear more directly on the problem of tragedy for D'Annunzio and his contemporaries; for now, however, we must comment on the Sogno, the "poema tragico" that by its very name denies itself the absolute aspiration to/of tragedy.

The play begins with the loss of a potentially full discourse that has been throughout history coupled to tragedy, namely, comedy. The comic world is exemplified by the servants who open the play's action, Panfilo (who "ha sempre il riso in bocca") and Simonetta. They serve more thanthe merely functional role of introducing necessary diegetic material to the audience: they are models of a comic alternative which is precluded from D'Annunzio's theatrical endeavor. Within the economy of the Dannunzian text, a comic interpretation of events- "we have but slumbr'd here, while these visions did appear"-is not among the set of possible strategies, for the reason that it renounces knowledge ("non so, non so" is the servants" refrain). The discourses set to work in the Sogno are precisely of the sort that make some attempt at being positive, positing themselves as potentially full vehicles of a knowledge. The figures of comedy are everywhere on the edges of the dream-space but nowhere within: "essi rimangono sul limitare; poi s'allontanano, si perdono nel bosco" (40). Panfilo's ritornello "Per una ghirlandetta," which begins and ends the play, is a music from another world, delimiting the discursive possibilities of the Sogno, exemplary of all that is not a part of it.

The first discourse to be considered is the enthymematic one of criticism, one that interprets the dream in objective terms, from the outside (which turns out to be the inside perspective of the villa and the historical culture it represents). The old keeper Teodata and the Doctor together interpret events according to a category of certainty (essere) that they believe themselves capable of applying to the world they look upon. Together, they represent two types of authoritative interpretation-a nonsecular, god-given, and a secular, scientific knowledge, respectively, whose authority is due to its link with the past, a past conceived as an accumulation of judgments. As bearers of this judgment they should possess the status of a chorus were it not for the radical division of the world into two opposing camps; in a post-classical age, they prove to be no more than isolated individuals. Hence, theirs are always (mis)interpretationsthe parenthesis perhaps captures the not complete falseness, the partiality, of their views. They shape the dream according to a putatively authoritative knowledge, figured in familial terms: his voice is "paterna" (28), she has "un cuore materno" (12). They have entered the dream-space in a spirit of critical understanding, a spirit that can only do injustice to the 
text it considers-in regard to Isabella's madness, for instance, their only ambition is one of critical closure, of a "miracolo" or a "risveglio."

Teodata has not been only a guardian in her life; for many years she had been "la lettrice paziente al capezzale di un'inferma [Isabella's mother]" (12) - a detail which takes on some significance in light of the Doctor's contention that "i libri non hanno affievolito le [sue] pupille." Her eyes have not been weakened, physically, to be sure, but also spiritually in the manner of an Emma Bovary. Teodata is alien to the ruses of literature and of desire; she reads objectively. Criticism, ideally, remains untouched by 'literature'-its eyes are always open. Its own fiction is one of competency, a fiction that must overlook "the dream's navel" (as Freud once put it), its ultimate recalcitrance to interpretation. Describing an encounter between Isabella and her lover's brother Virginio before the murder of this brother, Giuliano, she wonders if "quell' apparizione-che non aveva alcuna evidenza di verità-si confuse per sempre nel sogno violento che la dominava?" (13) In her role as careful reader she is able to see apparitions for what they are, to preface them with the knowledge of the waking world. When the Doctor asks her whether Virginio also loved Isabella she responds, in a gesture of interpretive supremacy, "Ah, io lo so; forse lo so io sola." The price of this certainty, however, is a falling short of the full 'truth' of the situation; her description of Virginio's love, which follows the above-cited profession of knowledge, is a blatantly limited one:

L'ho veduto inginocchiarsi su la terra ch'ella aveva premuta passando e cercare con le labbra i fili d'erbe che portavano il segno dell'orma. ... Che pietà e che tenerezza! (11).

Even to the most innocent reader of the Sogno this interpretation must seem a somewhat ludicrous version of Virginio's love. His desire for Isabella is clearly something more than pious and tender. The fetishism involved in kissing the earth a woman treads, emphasized by the sensual "cercare con le labbra" (a sensualism the old woman seems/is blind to at the same time that she announces it), falls outside Teodata's maternal reading.

The Doctor also provides us with a version of certitude, a mixture of science and romanticism that at first blush seems more compelling: "Ah, io comprendo, io comprendo" he asserts, interpreting Virginio's dream of curing Isabella as "un sogno giovenile e divino in cui la morte e la vita sono divenute una cosa sola, infinitamente più bella e piú grande della morte e della vita" (17). We are perhaps more tempted by the rhetoric of the Doctor's 'comprehension' than by Teodata's 'knowledge'especially since it echoes many of D'Annunzio's own statements about possible sublations of life and death (declamations which, as here, usurp 
for their own secular purposes a language of the sacred)—but the "forza animatrice" which he ascribes to Virginio and his belief that Virginio might utter some "parola miracolosa" to wake Isabella from her madness prove illusory constructions. Every interpretation of the dream-space, and every attempt to act upon it, is a missed one; and yet, like the enthymeme, each contains an element of truth. And this is so by virtue of their contact with the dream. Even as Teodata distorts the dream, it touches her and establishes an ephemeral, figural presence in her, as the Doctor points out:

Quali figure, Teodata! Chi vi suggerisce queste parole? Voi eravate attentissima. ... Voi siete sempre attentissima. . . La vita vi si rivela per apparizioni fulminee, come a una veggente (12).

Her words are touched with something other than their everyday aspect: they possess a virtue of figuration which has nothing to do with knowledge but with attention, attending-to appearances. In a critical move typical of the Doctor, he then goes on to cast her in the role of seer, confusing two types of vision. But it would be unfair to characterize the Doctor as no more than a mouthpiece of a mystico-scientistic ideology; he too is touched by the dream-and thus, in some way, actively touches it. In one of their dialogues, Isabella aligns his voice with that of a natural chorus:

La vostra voce non è mai discorde. Le vostre parole accompagnano sempre un coro naturale che è nell' aria, intorno a chi ode. Tutto diviene calmo e puro (28).

His voice is double, one of critical interpretation in which contradiction is regulated and made to accord, and another that appears to go beyond itself-a verbal accompaniment to the meaningless chorus of inhuman nature, "il sussurro delle api, il garrito delle rondini, e quel tintinnío [argentino dei mughetti]."

The unregulated voice is one that is affected with desire. To maintain the posture of objectivity criticism must hide its desire: the absoluteness after which it strives is only possible at the expense of this repression. In order for the desire that motivates criticism to be perceived, it must be exposed as rhetoric, as the manifestation of a persuasive-persuaded impulse, a (mis)interpretation touched by figurations. The 'affectedness' of the Doctor's language is, in this case, revealed not by another critic but by the object of critical study, the dreamer, whose desire is out in the open and at stake in the play. The dreamers, Isabella and Virginio, enact two sorts of desire, which, not surprisingly, take up the two major concerns of D'Annunzio's career to that point: his work in narrative and the lyric. The Dannunzian 'act' as it comes to be manifested in his theatre could be defined as a cross, a tension, between a narrative and a lyric project: 
the radical transformation of an other or one's self, respectively. In his theatre proper, the two projects are usually confined to one character; in the Sogno, however, they are analyzed separately in the persons of Virginio and Isabella. In order to achieve their goal both dreamers are prepared to traverse the dream-space, the realm of figurations, in a gamble that their actions, their heroism, will ultimately result in a real trasfigurazione of the object of their desire-be that object, as in the case of Virginio, an other whom he hopes, with a word, to awaken into a better world; or, as in the case of Isabella, her own self purified of all ties with the world of intersubjective desire. That these dreamt-of transfigurations are real impossibilities, albeit ideological necessities, will be the message of Dannunzianism.

Virginio's story, and the desire that motivates it, is a familiar romantic one: the pursuit of a transfiguring passion that would abolish the unhappy distance between himself and the object of his desire. The madness of his dead brother's lover, Isabella, must be overcome if his dream is to be realized, a dream in which-as he recounts it to her sister Beatrice-"le figure immobili e fosche della vita trascorsa si coloravano d'un bagliore prodigioso, irriconoscibili come le statue nell'incendio d'un tempio" (38). The juxtaposition of statues and fire marks his dream of redeeming the past, the unmoving figure, in an elemental presence-a redemption that would ensue from his heroic action of leading Isabella out of her madness and back into the world of desire for others. But no real action occurs in the Sogno: the incendiary present dreamt by Virginio proves a lure. If figures are mobilized upon the dream-space they soon recede back into or out of themselves, to the villa or the forest. The idea of passionate love to which Virginio's dream gives expression is a strategic fiction, a "mensonge romantique" as René Girard would call it. ${ }^{10}$ Virginio's desire initiates nothing: far from being spontaneous, it reveals itself as no more than an imitation, and hence never succeeds in distancing itself from the unredeemed past. Hidden by the ideological foregrounding of romantic passion is the essentially metonymic nature of the dramatic action that Virginio contemplates: the object is not desired in itself but because another desire has already traversed it.

What Virginio's dream at once hides and makes manifest is his relation to Giuliano, a relation of rivalry. That he desires Isabella because of his dead brother's desire for her is implicit in the manner of action that his dream leads Virginio to take: if he is to achieve his own ends in the narrative present of the play, he must re-present himself to the insensate Isabella as his own brother. In order to be loved for himself he must invoke the image of his brother, the condition of his own desire. The therapeutic 
effect that Virginio wishes to have on Isabella is to conjure up Giuliano to her mind and thereby exorcize him, replacing him; he wants her to relive the primary narrative which led to her madness, the "sogno violento" of her affair with Giuliano. But when the time for action comes, Virginio remains speechless, "impietrito," unable to utter a word: all the words he could utter are those of his rival, words of passion. The subject-object relation has nothing new to offer, it can only be repeated. The hoped-for catharsis and subsequent redemption of the immobile figure does not take place; the failure of Virginio's enterprise has as its only real result a reconciliation on his part with metonymic desire: at the play's end he retreats back into the villa with Isabella's sister Beatrice. The lack of a dramatic action, of a miraculous word, shows D'Annunzio's awareness of the impossibility of a real heroism. This awareness needs to be kept in mind when reading his other post-decadentist, and apparently more optimistic, works, such as Il Fuoco: the autobiographical hero Stelio Effrena, the "Animatore" who offers up the "parola dominatrice" to an eager public, should not be understood as a Virginio who succeeds but as a hero whose actions are tacitly limited to an imaginary space, no more (but no less) real than a dream.

According to Girard, "les êtres de passion sont infiniment rares dans l'univers post-révolutionnaire" (112). Passionate beings, those who, unlike Virginio, draw from themselves and not others the strength of their actions, are present in a writer like Stendhal, but significantly confined to the outer reaches of silence, the limns of the text. The total absence of such heroes is a sign of decadence (not for nothing is Stendhal the object of an intense literary nostalgia during the fin de siècle). The second of D'Annunzio's dreamers shares some traits with those autonomous "êtres de passion" whose disappearance is a symptom of the "male del tempo"--but this passion must, in the case of Isabella, be taken in its literal sense of passivity and suffering. She has a certain autonomy but one that can only be figured as dementia, as a pathological renouncement of the world of meaning and (triangular) desire. Her desire does not extend to others; rather, it encloses upon her self, forecasting a future state of trasfigurazione in which her passivity will become redeemed activity. The forecast, as will be seen, is integrally linked to a recasting of the past in a discursive strategy that we may call genealogical.

A large part of decadentism involves a manipulation of the language and thematics of the Gospel; ${ }^{11}$ since Christ's Transfiguration on Mount Tabor (Matt. 17:2) is contextually linked to Isabella's potential one, it is worth recalling here:

et transfiguratus est ante eos 
et resplenduit facies eius sicut sol

vestimenta autem eius facta sunt alba sicut nix.

(Matt. 17:2)

Isabella would be a metaphor of herself in the same way that Christ is of the Being he is. In effecting a passive trajectory from inside to out, across the garden-space, she is moving toward that which she is, toward that transfigured state which offers itself as a solution to the problem of decadence, a problem to which the critical and activist responses remain subject. Given this decadence, however, Christ's story is only indirectly available as a model: in the Sogno, the resplendent vertical imagery of the Gospel and its revelation of a timeless truth is supplanted by Isabella's horizontal movement from one side of the garden to another and a merely anticipated re-cognition of the transfigured body, a pre-figuring of it. It can only be pre-figured because the past, the old order, has yet to be fully overcome, a fact which is marked in terms of the play's seasonal chronology by the asymmetry between the violence of the autumn (Giuliano's murder) and the springtime of the tragic poem. As a result of her contiguity with the past she still speaks a language of common knowledge, albeit a skewed one, and her old desire can still be evoked, metonymically, as when she recoils from a red rose that reminds her of the bloody and dying Giuliano. In order to escape this condition she develops a strategy for persuading herself that her ties to the world of the villa can be overcome. This strategy is genealogical inasmuch as it involves a searching of the past for an antecedent story that would validate her desire to become who she is. The inventio of a first link in the chain of that self-becoming is necessary; since the traditional model of Christ is not directly available an alternate story must be found to construct this genealogy of the self.

Madonna Dianora, a fifteenth-century adultress who lived at the villa Armiranda, supplies the precedent which motivates Isabella's definitive break with the past. Dianora, who is said to haunt the villa in the form of a white peacock-alba sicut nix-is the necessary double of Isabella (a doubling that is pervasive in D'Annunzio one need only think of the two Cantelmos in the Vergini); her story fore-tells Isabella's final transfiguration into a thing white as snow-the peacock, or, elsewhere in the text, the white butterfly-and her liberation from the past and its evils. Before re-telling the story of Dianora to the Doctor, she asks him:

Voi conoscete la storia di Madonna Dianora all'Armiranda? Non vi ho mai mostrato il suo ritratto scolpito da Desiderio: quel piccolo busto d'un marmo cosí delicato e dorato che sembra quasi un miele impietrito? (23).

By a play on words, desire (Desiderio da Settignano was a fifteenth-century 
Florentine sculptor) is revealed, in the telling of the story, for what Virginio cannot see it as, the sculptor of the individual, a 'petrified' individual, unable to act on his or her own account. The two Dianoras, statue and transfigured being, supply Isabella with the positive model she requires: when Isabella tells her own story, in the climactic scene of the play, it will involve a similar revelation of desire's role in her life, an admission that should allow her to distance herself from the story she has told, to leave behind the world that desire made for her.

In describing Giuliano's death, Isabella modulates from the vocabulary of autonomous passion into one of 'petrification' that undermines the first. She begins with the moment of tragic passion:

La sua bocca mi versava tutto il sangue del suo cuore, ardente e puro come la fiamma, che mi soffocava ... Ah, com'erano piene le sue vene e di che ardore! Tutto l'ho ricevuto sopra di me, sopra la mia carne e sopra l'anima mia, fino all'ultima stilla ... (44-45).

Giuliano's giving of himself is marked by a symbolic rarefaction of the liquid element into blood. But the flesh quickly becomes a dead and icy weight, a thing of the past akin to the petrified Virginio before whom she finds herself at the end of the play. It loses its lightness as it ceases to give; she feels the corpse "farsi di gelo, irrigidire, pesare come la pietra, come il ferro, divenire veramente un cadavere, una cosa estranea." The rhetoric of presence (made up of words like "tutto" "puro" "piene" "fiamma" "anima") is gained only at the expense of a reconciliation with its real absence: this passion is a thing inscribed within the realm of a language that is not transfigured, statuesque, a part of the story. The Dannunzian Urszene, as Paolo Puppa calls it (127), takes place only in its linguistic re-enactment; it is a scene that in terms of the play never really was, never was anything more than the "sogno" that made possible the Sogno. The cathartic-sacrificial re-telling of the scene is the last step away from it-the sacrifice of her old desire coincides with a catharisis, frees her to go toward a future that is securely beyond the "motivational clusters" (to use a Burkean phrase) of desire and interpretation that form around her. She lapses toward the elemental outside of the forest and its visions of force and joy. At play's end she is voided of desire and its language: the new self prepared for in her discursive practices is about to be realized.

This new found reality does not, however, resolve the "male del tempo" but constitutes one half of the division which makes up that evil. Isabella is now immune to the evil but helpless to fight it because she is on one side, to one side of the language which must combat it. In language, the 
truth of the transfiguration can only be pre-figured; a secure ontological identification of/with the full body must wait. The truth beyond the partial truths which language gives expression to cannot be spoken: the flowers of the outside world "stanno per sbocciare," are on the point of flowering, but will not open until the play has ended-a sentiment Foucault also evokes when he says, with regard to madness, "la vérité de l'homme ne se dit que dans le moment de sa disparition; elle ne se manifeste que devenue déjà autre qu'elle-même" (545). Far from offering Isabella as a positive instance of the vitalistic cult of self-becoming, D'Annunzio shows how that cult enables itself as a discourse, the strategic practices that it sets in motion. Lyric heroism remains a pre-figuring that can only accomplish itself by disfiguring itself, by ceasing to be. Implicit in this position is the refusal of a poetic of the transcendent word, of the word as music beyond the boundary of an everyday language-or, rather, a refusal of this poetic word as expressive of truth. This sacrifice makes possible the poetic cadences of Alcyone, just as the critique of action evidenced in Virginio's failure prepares for the action of the tragedies.

What is beyond the gate is not fraught with the evil of time, but neither is it resolveable in speech, and for this reason the beyond to which D'Annunzio so often gestures cannot be his place of resolution. If there is to be an intimate "connubio dell'arte con la vita" as he suggests, it will consist in a recourse to language, conceived as a labile field of persuasions able to resist time only at the price of hardening into ideologies. Madness, silence, a strange music, superomismo, the aristocratism that Valesio rightly identifies with D'Annunzio-these can be nothing more than dreams. As Isabella enters life, at the limit of the world of meaning, "alle soglie del mondo visibile," her potentially prophetic words-those of a transfigured, Christ-like body-are covered over by the song of comedy, Panfilo's ritornello which began the play. This song has already been excluded from the beginning; its emptiness thus marks the emptiness of what it covers over. Within language, and we are always within, the "insubstantial pageant" of desire and interpretation continues, "rounded with a sleep."

$* * * * *$

D'Annunzio's shift from the pessimistic register of the late 1880 s and early 1890 s to the ostensibly optimistic, dionysiac and post-decadentist one of his tragic theatre is an attempt to come to terms with the new historical reality of mass society. From the pessimism of an essentialist position (the world is decadent), he comes to the realization that, as one researcher into 
the nature of the fin de siècle has put it, this so-called decadence is only a manifestation of historical change, "una trasformazione in una diversa società e civiltà, e quindi in una concezione diversa del fatto letterario: in una civiltà e in un'arte di massa" (Petronio 24). This realization pushes him toward the adoption of an ideology that would be capable of reaching a mass audience; the prime requirement of such an ideology was pointed out by Gustave Le Bon, the French theorist of crowd psychology, in his 1894 study of the evolution and decay of peoples:

Les foules se tourneront toujours vers ceux qui lui parleront de vérités absolues et dédaigneront les autres. Pour être homme d'Etat, il faut savoir pénétrer dans l'âme de la multitude, comprendre ses rêves et abandonner les abstractions philosophiques (164).

The aims of ideology in this late nineteenth-century context are clear: if the crowd is to become an audience, it must be addressed in terms of "absolute truth." The true statesman must be able to give expression to the dream of the crowd and posit it as his own if he is to be listened to; his own aristocratic dream must be sacrificed, at least on a literal level, to the necessities of the absolute idea which mass society requires. Hence the duplicity of the Dannunzian text, its openness to both a vulgar and an allegorical reading. Yet both ideologies, the properly Dannunzian one and that which can be heard by the masses, fall victim to the work of D'Annunzio the rhetorician, for whom their truths are always partial, always open to the kind of analysis that he makes explicit in the Sogno. D'Annunzio offers up dreams to the masses and to his disciples, offers them as real models of action for all that he affirms them to be dreams (and hence not real). As ideologue, as tragedian, he offers the dream of truth, of a full and heroic discourse, be it a vulgar or a subtly Dannunzian heroism; under the light of his rhetorical analysis all such positive content has the status of error. The erasure of such analysis in the tragedies allows this error to speak in the voice of truth.

This allowance for error enables the emergence of an authentically tragic modern theatre-something that Pirandello had, in an early essay called La menzogna del sentimento nell'arte (1890), diagnosed as practically impossible. He there laments the loss of an eternal harmony, one that derived from an exact conception of life and of man:

È appunto quest'armonia ... che ora manca a noi, a causa delle nostre condizioni morali e sociali, e però non abbiamo ancora un teatro, e checché si faccia e si dica, difficilmente 1'avremo. I Greci che l'ebbero, ebbero anche un teatro glorioso, perché poterono serenamente contemplare ogni errore, cui deve sempre fatalmente seguire una catastrofe. Noi sentiamo troppo, soffriamo troppo: la 
nostra vita è per sé stessa drammatica, però non possiamo aver la serenità di concepire il dramma, da che noi stessi vi siamo impigliati (870).

Pirandello's own modernist resolution of this dilemma is well-known; what is important here, though, is that D'Annunzio's theatre emerges out of a meditation on the same problem. Because we ourselves are engaged in the drama of our life and hence are condemned to pursuing actions that serve our own purposes, that are mere persuasions couched in an ideology justifying them, we cannot achieve the fullness, the harmony which ensures the possibility of a tragic theatre. That all gestures are partial, at a remove from the attainment of such "armonia," is the kernel insight of Dannunzianism. Reality, a real temporality that is lived and not only spoken about, remains forever a project, a projection that language can only pre-figure. The tragic theatre can only come into being, can only escape the partiality of discourse to which it is restricted, by an untenably ideological assertion of the harmony which is its necessary and impossible precondition.

The solution that a tragic theatre would represent to our problems is for us always already deprived of its hygienic role as catharsis; the conflict between man and nature which Greek tragedy, in Pirandello's account, serenely contemplated is for us inconceivable, immersed as we are in it. At best it skirts the margins of language, as Valesio has pointed out in relation to Hölderlin's fragments: "la tragedia moderna è lirica non drammatica, non corale. Eppure le propaggine, il fantasma del coro è rimasto" ("Il coro" 66). It is the phantasm, the dream of a tragedy, that constitutes the tragic enterprise conceived by D'Annunzio. The evil of time, the error from which derives the catastrophe, remains untouched-and yet, for all that, action is pursued by the Dannunzian hero, both as the quest for a suitable object to desire and as the impulse toward self-transfiguration. The impossibility of these pursuits mirrors that which faces the author: to write a modern tragedy is to engage in a dream. Were it not for the existence of the Sogno, which, standing as a protocol to the enterprise, teaches us how to read the tragedies, one could well level the charge of inauthenticity against his theatre, a theatre that appears to wish a reduplication of Greek tragedy and the incarnation of Nietzschean supermen. But, from the beginning, he has emphasized the partial nature of his tragedies, their inevitable falling-short of the status of real tragedy, a reality which is beyond us. In a world where "everything unconditional belongs in pathology," 12 it is this obliquely-imposed limitation of a seemingly grandiose enterprise that guarantees the 'health' of D'Annunzio's theatre.

In a reading of D'Annunzio that registers these limitations, we contem- 
plate the error of modern times without emerging from it. The counteraffirmation voiced in D'Annunzio's rhetorical commentary, insisting as it does on the ideological nature of all affirmation, ensures that the philosophical speculation of Dannunzianism-its commitment to a non-totalizing ethos-is not lost sight of in its deference to the truths required by mass society or the "free spirits" who follow him more closely. Tragedy, for D'Annunzio, means allowing the error of his times and of his enterprise to speak: he adopts the totalizing symbolic language of his characters despite the fact that he is conscious of and has revealed its erroneousness. He re-signs himself to it; by the force of this re-signation his dream ceases to be the abulic one of a self-involved decadentism. The dream proves a necessary error-something like what Leopardi once called "il mio possente error" (Canto XXII). The only viable critique of decadence, D'Annunzio appears to be saying, is one that maintains itself within the human condition of men condemned both to language and impossible acts.

\section{Stanford University}

\section{NOTES}

1 Within the context of this essay the crucial role of the Vergini in D'Annunzio's move away from decadentism cannot be elaborated on. The reader should consult Lucia Re's formidable study, “Gabriele D'Annunzio's Novel Le Vergini delle rocce: 'Una cosa naturale vista in un grande specchio'," Stanford Italian Review 3.2 (1983): 241-71.

$2 \mathrm{La}$ Rochelle 152. Vattimo's recent interpretation of the Nietzschean superman as one who continues to dream "sapendo di sognare" (27-50) strikes me as the most appropriate starting-point for tracing the affiliation between Nietzscheanism and Dannunzianism.

3 Jacobbi 5. For reasons of space, discussion of D'Annunzio's other dramatic dreamtext, Sogno d'un tramonto d'autunno (1899), cannot be included here.

4 This is not to make the extreme, and patently false, claim that D'Annunzio shows the ease of language here that we find in his so-called canonical works. That well-known "perfezione che suona falsa" spoken of by Serra 238 is absent from the Sogno. As Valesio has pointed out to me in regard to the Sogno, "the text marks the beginning of D'Annunzio's work in the dramatic genre; while his basic semiotic rhetorical structure is already effective and sophisticated, his language is still a little rigid."

5 For a good introduction to D'Annunzio's theatre in the context of symbolism, see Marazzini 276-87.

6 For an analysis of the didascalia, see Guidotti 17-31.

7 The terms are from a proposed typology of discourses in Barthes 53. He associates the enthymematic with intellectual discourse, the metonymic with narrative, and the metaphoric with lyric poetry and sapiential discourse.

8 The discussion of Virginio's dream is generated out of Girard. Meditations on male rivalry-emulation become more explicit and frequent in D'Annunzio's last novels and the autobiographical war writings.

9 See Valesio, "Il coro 68-70. For a discussion of Christological passion in the late 
D'Annunzio that reflects back interestingly on earlier work, see Spackman 218-29. 10 "Alles Unbedingte gehört in die Pathologie"-Nietzsche 6.2: 100.

\section{WORKS CITED}

AURISPA, Giorgio. Prose di romanzi. 2 vols. Milan: Mondadori, 1955.

BARTHES, Roland. "Introduction à l'analyse structurelle des récits." In R. Barthes et al., Poétique du Récit. Paris: Seuil, 1977.

BINNI, Walter. La poetica del Decadentismo. Florence: Sansoni, 1968.

D'ANNUNZIO, Gabriele. Tragedie sogni e misteri. 2 vols. Milan: Mondadori, 1954.

FOUCAULT, Michel. Histoire de la folie d l'âge classique. Paris: Gallimard, 1972.

GIBELLINI, Pietro. "Parole per il 'Sogno." Quaderni del Vittoriale 8 (1978).

GIRARD, Renè. Mensonge romantique et vérité romanesque. Paris: Grasset, 1961.

GUIDOTTI, Angela. "Strutture sceniche e strutture narrative nei due 'sogni' dannunziani." Rivista italiana di drammaturgia 3.7 (1978).

HUYSMANS, J.K. Oeuvres completes. 18 vols. Geneva: Statkine Reprints, 1972.

JACOBBI, Ruggero. "Cinque capitoli dannunziani." Rivista italiana di drammaturgia 3.7 (1978).

JONARD, Norbert. "D'Annunzio romanziere decadente." Quaderni del Vittoriale 36 (1982).

LA ROCHELLE, Pierre Drieu. Sur les écrivains. Paris: Gallimard, 1964.

LE BON, Gustave. Lois psychologiques de l'évolution des peuples. Paris: Félix Alean, 1907.

MARAZZINI, Claudio. "Le mani, lo specchio, la 'Tentation de Saint Antoine': classicismo e simbolismo nelle tragedie dannunziane." Sigma 9.1-2 (1976).

NIETZSCHE, Friedrich. Jenseits von gut und Böse. Werke. 8 vols. Berlin: Walter de Gruyter, 1968.

PETRONIO, Giuseppe. "Il 'Decadentismo': La parola e la cosa." Quaderni del Vittoriale 36 (1982).

PIRANDELLO, Luigi. Saggi poesie e scritti varii. Milan: Mondadori, 1960.

PUPPA, Paolo. “D'Annunzio: Teatro e mito.” Quaderni del Vittoriale 36 (1972).

RAIMONDI, Ezio. Il silenzio della Gorgone. Bologna: Zanichelli, 1980.

$\mathrm{RE}$, Lucia. "Gabriele D'Annunzio's Novel Le vergini delle rocce: 'Una cosa naturale vista in un grande specchio." Stanford Italian Review 3.2 (1983).

SERRA, Renato. Scritti letterari, morali e politici. Turin: Einaudi, 1974.

SPACKMAN, Barbara. "Il verbo (e)sangue: Gabriele D'Annunzio and the Ritualization of Violence." Quaderni d'italianistica 4.2 (1983).

VALESIO, Paolo. "The Lion and the Ass: The Case for D'Annunzio's Novels." Yale Italian Studies 1.1 (1977).

. "The Beautiful Lie: Heroic Individuality and Fascism." Reconstructing Individualism: Autonomy, Individuality, and the Self in Western Thought. Stanford: Stanford U P, 1986.

. "ll coro degli agrigentini." Quaderni del Vittoriale 36 (1982).

. Novantiqua: Rhetorics as a Contemporary Theory. Bloomington: Indiana U P, 1980.

VATTIMO, Giovanni. "Nietzche e l'al di là del soggetto." Al di la del soggetto. Milan:

Feltrinelli, 1984. 